судебную защиту и восстановление конституционных прав и свобод участников уголовного процесса, а также обеспечения гражданам доступа к правосудию.

$$
* * *
$$

1. Махов Н.Н. Правосудие в России: проблемы и решения. Красноярск, 2010. С. 156 - 170.

2. Алехин К.Е. Судоустройство и судопроизводство в РФ: Учебник для вузов. Калининград, 2011. $617 \mathrm{c}$.

3. Актуальные проблемы деятельности судов общей юрисдикции Российской Федерации: Учебник / под ред. В.М. Бозрова. М.: Юстиция, 2017. 568c.

4. Таричко И.Ю. Функция судебного контроля в Российском уголовном процессе: Дис. ... канд. юрид. наук. Омск, 2004. 226с.

5. Ковтун Н.Н. Судебный контроль в уголовном судопроизводстве России. Н. Новгород: Нижегородская правовая академия, 2002. 520с.

6. Ерохина О.С. Сущность участия следователя в судебном заседании в ходе досудебного производства по уголовному делу // Евразийский юридический журнал. 2011. № 11 (42). С. 123 127.

7. Судебная власть и правосудие в Российской Федерации: Курс лекций / Под ред. В.В. Ершова. М.: РАП, 2011. 904c.

8. Воскобитова Л.А. Механизм реализации судебной власти посредством уголовного судопроизводства: Дис. ... д-ра юрид. наук. М., 2004. 460с.

\title{
Попов А.В. \\ Актуальные вопросы организации оперативно-розыскной деятельности по раскрытию убийств, совершаемых по найму
}

Академия управления МВД России

(Россия, Москва)

doi:10.18411/spc-20-01-2018-05

idsp: 000001:spc-20-01-2018-05

Заказные убийства, как правило, совершаются в условиях неочевидности, в результате чего в большинстве случаев достаточно трудно выявить признаки, на основании которых можно сделать вывод об убийстве совершённом по найму.

Данный вид преступлений имеет определённую схему подготовки и совершения: «ПОТЕРПЕВШИЙ - НАНИМАТЕЛЬ - ПОСОБНИК - ПОСРЕДНИК НАЕМНИК (ИСПОЛНИТЕЛЬ)». Данные обстоятельства оказывают влияние на методы и формы документирования.

По делам об убийствах, в отношении которых выдвигается версия о их совершении по найму, первоначальный этап раскрытия должен привести к основаниям выдвижения такой версии. Поэтому, на первоначальном этапе раскрытия убийства как совершенного по найму, можно утверждать, только тогда, когда для этого имеются необходимые основания.

Традиционным направлением раскрытия заказного, как и иного, убийства, является работа «от преступления - к лицу». Она организуется в соответствии с информацией и данными, полученными на месте происшествия. Анализ материальных следов (огнестрельное и холодное оружие, боеприпасы, следы крови, пули, извлеченные из трупа, гильзы, пыжи, окурки и т. п.) приводит к выдвижению оперативно-розыскных версий. Поэтому основное значение имеет своевременное обнаружение и изъятие на месте происшествия следов рук и других криминалистически значимых следов, вещественных доказательств, оставленных преступниками и их сообщниками. В сочетании с данными, полученными оперативнорозыскным путем, собранные материалы могут способствовать обеспечению наступательности в поиске преступников. Например, по изъятому с места происшествия оружию, помимо следственных действий, проводится ряд оперативнорозыскных мероприятий:

- проверка по соответствующим учетам; 
- отслеживание по цепочке владельцев;

- установление источника приобретения или каналов приобретения оставленного преступниками оружия;

- проверка оружия по имеющимся криминалистическим и оперативнорозыскным учетам НЦБ Интерпола, ГИАЦ МВД России.

Алгоритм действий следственно-оперативной группы на первоначальном этапе работы по уголовному делу может быть следующим:

- осмотр места происшествия и трупа;

- поквартирный обход с целью установления очевидцев (свидетелей) совершенного преступления, обстоятельств его совершения, личности потерпевшего;

- изъятие пуль, гильз, следов пальцев рук, биологических (в том числе запаховых) следов, микрочастиц и иных объектов;

- ориентирование территориальных и транспортных органов внутренних дел, оперативных подразделений системы исполнения уголовного наказания по обстоятельствам совершенного преступления;

- составление субъективных портретов предполагаемых участников убийства и сверка изображений по фототеке, региональному учету в АБД «Наемники». В целях возможного получения необходимой информации от населения используются средства массовой информации.

- назначаются и проводятся необходимые судебные экспертизы (криминалистические, судебно-медицинские, биологические и т.п. ).

- сотрудниками СОГ производятся обыска и выемки по месту жительства и работы потерпевшего, организовывается изучение и осмотр записных книжек, блокнотов, телефонных справочников и других документов, принадлежавших жертве преступления, а также допрос родственников, знакомых и сослуживцев. Обследуются близлежащие территории на наличие брошенного автотранспорта. Организуется просмотр и при необходимости изъятие видеоизображений с камер видео-наблюдений, как на месте преступления так и по ходу движения потерпевшего и по предполагаемому маршруту передвижения "отхода" преступника. С целью установления причастности и получение какой-либо значимой информации по совершённому преступлению, проводится проверка криминально активных лиц, включая лидеров и авторитетов преступной среды.

В последнее время некоторое распространение получили убийства, совершенные с применением взрывных устройств. Их раскрытие имеет особенности, и требуют привлечения к работе помимо сотрудников оперативных подразделений МВД, ФСБ, следователя СК и эксперта-криминалиста (в том числе эксперта-взрывотехника). В его компетенцию входит уточнение границ безопасной зоны, организация оцепления по ее границам, определение возможности работы с отпечатками пальцев, использования фото- и видеосъемки взрывного устройства, проведение работ по его обезвреживанию, рекомендаций следователю о порядке изъятия, упаковки и транспортировки или о необходимости уничтожения на месте, оказание иной помощи. Действия по обезвреживанию взрывного устройства, его демонтажу или уничтожению оформляются протоколом, который впоследствии направляется на экспертизу вместе с вещественными доказательствами.

Раскрытие и расследование убийств, совершенных с использованием взрывных устройств проводится, как правило, специализированными следственно-оперативным группами, в состав которых включаются специалисты взрывного дела (саперывзрывники, пиротехники, металловеды и др.). 
Особую категорию заказных убийств, представляют преступления, замаскированные под безвестное исчезновение граждан. Указанная проблема характеризуется рядом особенностей, в значительной степени определяющих своеобразие организации и тактики раскрытия таких преступлений.

Характерно отсутствие трупа или вещественных доказательств, прямо указывающих на совершенное преступление к моменту рассмотрения заявления, что заведомо ставит под вопрос само событие преступления. Здесь приходится устанавливать сам факт преступления, выявляя его признаки, принимать меры к розыску трупа и одновременно искать самого исчезнувшего, вести тщательную проверку известных или устанавливать иных лиц, причастных к исчезновению субъекта.

Сотрудники уголовного розыска применяют следующие меры по раскрытию преступлений такой категории:

- установление факта продажи свой квартиры или иной формы отчуждения конкретным лицам;

- отработка предпринимателей и «черных риелторов», принимавших участие при купле-продаже жилья;

- проверка отказных материалов по фактам смерти одиноких граждан, приватизировавших и продавших свои квартиры с правом пожизненного проживания.

- опрос лиц, хорошо знавших исчезнувшего, в том числе - членов его семьи, родственников, соседей, сослуживцев и т.д.

В целом, изучение следственной и оперативно-розыскной практики первоначального этапа работы по делу об убийстве, как совершенном по найму, позволяет вычленить некоторые из оснований для выдвижения данной версии, прямо или косвенно указывающие на наемный характер преступления. Важнейшее значение имеет изучение личности потерпевшего, направленное на установление его связей как с целью выявления сфер мотивации совершенного убийства, так и определения потенциального круга лиц, к числу которых может принадлежать его заказчик. Значение этой работы вытекает из базисной особенности заказного убийства - наличия обязательной связи потерпевшего с заказчиком. Это определяет организацию и тактику работы по принципу: «от личности потерпевшего - к инициатору (заказчику) преступления». Она также направлена на установление мотивов убийства. Например, в ряде зарубежных стран при организации работы по делам такой категории сотрудники полиции пользуются специальным вопросниками, которые содержат следующий алгоритм:

- сбор данных о характере деятельности потерпевшего, ее легальных и нелегальных сторонах;

- изучение образа жизни и поведения потерпевшего по месту его жительства и службы, как в прошлом, так и в настоящем;

- сбор данных, характеризующих личностные особенности жертвы;

- выявление, обобщение и анализ сведений о поведении потерпевшего в свободное от работы либо учебы время, вне семьи, в узком кругу знакомых, а также о его интимных и иных связях, общественной или политической деятельности.

В ходе оперативно-розыскных мероприятий, важное место отводится мероприятиям, которые направлены на определение круга лиц, среди которых необходимо определить наиболее вероятного заказчика или исполнителя преступления. Поскольку нередко круг связей жертвы оказывается весьма широким, возникает ряд самостоятельных промежуточных задач по упорядочиванию связей, определению приоритетов в их оперативной отработке, распределению имеющихся в распоряжении 
сил и средств. По-существу, здесь возникает весь комплекс вопросов планирования оперативно-розыскной деятельности.

Таким образом, одной из основных задач на первоначальном этапе, является сбор и накопление информации в отношении круга лиц, которые могут быть причастными к совершению убийства.

Следующее направление работы может строится по принципу: «от нанимателя к наемнику-убийце или посреднику». Такая схема реализуется при наличии информации о предполагаемом нанимателе или заказчике убийства. Как уже отмечалось, эти участники образуют преступную группу, сформированную единой целью совершения убийства конкретного лица по договору найма с заказчиком.

Алгоритм действий по данной схеме предусматривает:

- изучение образа жизни, поведения лица, предполагаемого в качестве нанимателя, по месту его жительства, работы (учебы), выявление его связей и их оперативную отработку;

- получение информации о том, что наниматель вел поиск посредника либо наемника;

- изучение профессиональной (финансово-экономической, коммерческой и пр.) деятельности предполагаемого нанимателя или посредника.

Поскольку осуществление такой проверки требует специальных знаний к ее проведению целесообразно привлекать сотрудников ЭБиПК ОВД. В ходе таких проверок могут быть установлены факты:

- использования фигурантом денежных средств потерпевшего;

- должники, бравшие кредит в фирме нанимателя и оказавшиеся не платежеспособными;

- информация о «выбивании» денег у нанимателя незаконными методами;

- связи, поддерживаемые нанимателем, в интересах обеспечения личной безопасности, а также безопасности функционирования предприятия, с преступными группировками, контролирующими данный вид бизнеса;

- конфликтные ситуации, имевшие место между нанимателем и потерпевшим по вопросам сфер влияния и видов предпринимательской (как легальной, так и нелегальной) деятельности.

Для последующего этапа работы по раскрытию «заказного» убийства, чаще всего, характерны две основные тактические ситуации:

- когда преступников установить не удалось;

- когда имеются подозреваемые, или обвиняемые в совершении преступления.

В первом случае работа организуется в плановом порядке, предусматривающем разработку версий, направлений, исполнителей и сроки выполнения мероприятий. Основой являются следственные, а также оперативно-розыскные версии. В целом организация раскрытия преступления на этом этапе работы носит характер оперативнотактического планирования, который включает в себя три основных элемента:

1) выдвижение версий об объектах поиска, их признаках, местонахождении и пр.;

2) определение подлежащих решению оперативно-тактических задач;

3) определение наиболее эффективных путей их решения.

Основой оперативно-тактического планирования является оценка тактической ситуации и прогноз тенденций ее развития. В свою очередь, оценка ситуации основывается на имеющейся информации и уровне ее аналитической проработки.

Исходными данными для построения версий чаще всего являются:

- результаты анализа сведений, полученных при осмотре места происшествия и прилегающей к нему местности; 
- сведения, полученные от свидетелей;

- данные изучения связей потерпевшего, результаты их проверки по оперативно-розыскным и иным учетам;

- сведения, полученные в ходе ОРМ, а также аналитические и обзорные материалы.

Чаще всего выдвигаются и отрабатываются следующие типовые версии:

1) убийство совершено лицами, с которыми потерпевший, возможно, соперничал из-за раздела (передела) сферы влияния;

2) убийство совершено кем-либо из числа связей потерпевшего на основе предпринимательских отношений;

3) убийство совершено лицами из числа должников или по их найму;

4) убийство совершено лицами из числа предпринимателей, с которыми потерпевший конкурировал либо конфликтовал, или по их «заказу»;

5) убийство совершено лицами, которые предъявляли претензии финансового и иного характера;

6) убийство совершено по политическим мотивам (противниками взглядов и убеждений потерпевшего;

7) из чувства мести;

8) убийство совершено на почве бытовых отношений (например, жена заказывает убийство своего мужа из-за неприязненных к нему отношений;

9) по иным, в том числе корыстным, мотивам.

В числе последующих оперативно-розыскных и иных мероприятий, осуществляемых в целях проверки названных версий, обычно проводятся:

- проверка финансово-хозяйственной деятельности фирм фигурантов;

- дополнительные или уточняющие опросы граждан, могущих обладать информацией об обстоятельствах совершенного преступления;

- дополнительное ориентирование территориальных органов внутренних дел и органов внутренних дел на транспорте.

- «отработка» ранее судимых за аналогичное, либо за иное тяжкое преступление;

- установление лиц, которые могли знать, с кем потерпевший до его смерти вступал в конфликт;

- одалживал крупную сумму денег;

- проверка лиц, близко связанных с потерпевшим;

- установление лиц, временно прибывших в данную местность и внезапно покинувших ее сразу же после убийства;

- установление криминально активных лиц, проживающих в городе (районе), где совершено убийство (в том числе, наркоманов, ранее судимых за тяжкие и особо тяжкие преступления и др.), и организацию их проверки.

Практика показывает, что указанные мероприятия проводятся практически по всем расследуемым делам, связанным с отработкой версии о заказном характере убийства. В ходе их проведения оперативные аппараты получают сведения о причастности к совершению преступления конкретных лиц из числа связей потерпевшего. Их проверка осуществляется оперативно-розыскными силами и средствами.

О заказном характере преступления могут свидетельствовать следующие полученные сведения:

- ранее поступившая в ОВД информация об угрозе убийства, высказанная в адрес жертвы; 
- принадлежность жертвы к предпринимательской структуре или к какойлибо преступной группировке;

- затяжной конфликт среди членов коллектива, которым потерпевший руководил;

- факт получения безвестно исчезнувшим лицом крупной суммы денег;

- наличие у потерпевшего криминального прошлого.

В случае проверки версии об убийстве в связи с профессиональной деятельностью потерпевшего, как правило, привлекаются:

- квалифицированные сотрудники ЭБиПК ОВД;

- представители налоговых служб, которые изучают финансовохозяйственную деятельность коммерческой и иной структуры, в которой потерпевший занимал руководящее положение;

- бухгалтерские работники, которые проверяют движение материальных и денежных средств по бухгалтерским счетам, кредиторская и дебиторская задолженность.

Указанные сотрудники проверяют финансово-хозяйственные документы на характер и содержание проводимых операций за определенный период времени, а также соблюдение гражданского и налогового законодательства.

Как свидетельствует практика организации раскрытия убийств, совершаемых по найму, не может быть успешным без постоянного взаимодействия подразделений уголовного розыска с другими оперативными подразделениями Министерства внутренних дел.

В результате чего, работа подразделений уголовного розыска и других оперативных подразделений, на последующем этапе раскрытия заказных убийств концентрируется, главным образом на установлении лиц, причастных к их совершению и оперативном сопровождении уголовного дела не только на стадии расследования, но и рассмотрения его в суде.

$$
* * *
$$

1. Парфенов А.В., Ковалев В.Н., Билоус Е.Н. Организация оперативно-розыскной деятельности органов внутренних дел по раскрытию убийств, связанных с безвестным исчезновением граждан: учебно-методическое пособие. М.: Академия управления МВД России. 2014. С. 23-24.

2. Парфенов А.В., Владимиров С.И. Использование психологической информации в организации оперативно-розыскной деятельности по раскрытию преступлений против жизни, половой неприкосновенности и половой свободы личности: учебно-методическое пособие. М.: Академия управления МВД России. 2017. С. 35-36.

3. Парфенов А.В. Некоторые особенности раскрытия убийств, связанных с безвестным исчезновением граждан / А.В. Парфенов // Труды Академии управления МВД России, 2011. №3. С. 76-77.

\section{Сидорина Д.Е., Гагарина О.Ю. \\ Доказывание по делам о возвращении ребенка или об осуществлении прав доступа на основании международного договора Российской Федерации}

Российский государственный университет правосудия Санкт-Петербургский Горный Университет (Россия, Санкт - Петербург)

doi:10.18411/spc-20-01-2018-06

idsp: 000001:spc-20-01-2018-06

\section{Аннотация}

Статья посвящена особенностям института доказывания по делам о возвращении ребенка или об осуществлении прав доступа на основании международного договора Российской Федерации, обусловленных характером 